ARTICLE

DOI: $10.1038 / s 41467-018-07457-7$

\title{
Major intensification of Atlantic overturning circulation at the onset of Paleogene greenhouse warmth
}

\author{
S.J. Batenburg (10 1,2, S. Voigt ${ }^{1}$, O. Friedrich ${ }^{3}$, A.H. Osborne ${ }^{4}$, A. Bornemann (1) ${ }^{5}$, T. Klein ${ }^{1}$, L. Pérez-Díaz ${ }^{6} \&$ \\ M. Frank ${ }^{4}$
}

During the Late Cretaceous and early Cenozoic the Earth experienced prolonged climatic cooling most likely caused by decreasing volcanic activity and atmospheric $\mathrm{CO}_{2}$ levels. However, the causes and mechanisms of subsequent major global warming culminating in the late Paleocene to Eocene greenhouse climate remain enigmatic. We present deep and intermediate water $\mathrm{Nd}$-isotope records from the North and South Atlantic to decipher the control of the opening Atlantic Ocean on ocean circulation and its linkages to the evolution of global climate. The marked convergence of $\mathrm{Nd}$-isotope signatures 59 million years ago indicates a major intensification of deep-water exchange between the North and South Atlantic, which coincided with the turning point of deep-water temperatures towards early Paleogene warming. We propose that this intensification of Atlantic overturning circulation in concert with increased atmospheric $\mathrm{CO}_{2}$ from continental rifting marked a climatic tipping point contributing to a more efficient distribution of heat over the planet.

\footnotetext{
${ }^{1}$ Institut für Geowissenschaften, Goethe-Universität Frankfurt, Altenhöferallee 1, Frankfurt am Main 60438, Germany. ${ }^{2}$ Department of Earth Sciences, University of Oxford, South Parks Road, Oxford OX1 3AN, UK. ${ }^{3}$ Institut für Geowissenschaften, Ruprecht-Karls-Universität Heidelberg, Im Neuenheimer Feld 234-236, 69120 Heidelberg, Germany. ${ }^{4}$ GEOMAR Helmholtz-Zentrum für Ozeanforschung Kiel, Wischhofstr. 1-3, Kiel 24148, Germany. ${ }^{5}$ Bundesanstalt für Geowissenschaften und Rohstoffe, Stilleweg 2, 30655 Hannover, Germany. ${ }^{6}$ Department of Earth Sciences, Royal Holloway, University of London, Egham TW20 OEX, UK. Correspondence and requests for materials should be addressed to S.J.B. (email: sietske.batenburg@earth.ox.ac.uk)
} 
T he Earth underwent long-term climatic cooling between the peak-greenhouse intervals of the mid-Cretaceous and the Eocene ${ }^{1-5}$. Globally averaged deep-water temperatures gradually declined by almost $10^{\circ} \mathrm{C}$ from 72 to $59 \mathrm{Ma}$, as estimated from benthic foraminiferal oxygen-isotope data ${ }^{3,6}$. This cooling has been ascribed to decreasing atmospheric $\mathrm{CO}_{2}$ levels ${ }^{7-9}$ through global reduction of volcanism and sea-floor spreading rates ${ }^{10}$ combined with changes in ocean circulation patterns ${ }^{3}$. In contrast, there is no comprehensive model explaining how the greenhouse conditions of the Eocene were established and what the roles of atmospheric $\mathrm{CO}_{2}$ and ocean circulation were in promoting global warming. Mechanisms proposed so far have solely focussed on increased atmospheric $\mathrm{CO}_{2}$ levels either induced by carbon cycle changes ${ }^{6}$, rates of continental rifting ${ }^{11}$, or by enhanced volcanism of the North Atlantic igneous province ${ }^{12,13}$. The role of changes in overturning circulation caused by the opening of the Atlantic Ocean and related changes in oceanic heat transport has, however, not been addressed yet.

While circum-equatorial flow, which had dominated circulation in the proto-North Atlantic earlier in the Cretaceous, gradually declined ${ }^{14}$, the ongoing opening and deepening of the Atlantic basin ${ }^{15,16}$ led to increased North-South connectivity, although the timing of the establishment of a deep-water connection remains debated ${ }^{17-22}$. Enhanced latitudinal water-mass exchange likely promoted the distribution of heat across the planet via the thermohaline conveyor and resulted in reduced temperature contrasts between the equator and the poles. To distinguish tectonic constraints on circulation from climatically driven changes, the role of subsiding submarine barriers has to be assessed. We determine the timing of the establishment of a persistent deep-water connection between the North and South
Atlantic by combining deep-water neodymium $(\mathrm{Nd})$ isotope and temperature records.

Assessing the role of ocean circulation on Earth's climate in the latest Cretaceous and early Paleogene requires tight constraints on the modes and locations of deep-water formation and the extent of mixing of different deep-water masses. Information on past water mass mixing and exchange can be derived from $\mathrm{Nd}$ isotope signatures $\left({ }^{143} \mathrm{Nd} /{ }^{144} \mathrm{Nd}\right.$, expressed as $\left.\varepsilon_{\mathrm{Nd}(\mathrm{t})}\right)$ of authigenic, seawater-derived sedimentary archives such as ferromanganese coatings of sediment particles or fish debris, which have been demonstrated to incorporate the Nd-isotope composition of ambient deep waters ${ }^{23}$. Deep-water masses mainly acquire their $\mathrm{Nd}$-isotope signatures from continental contributions via rivers and dust inputs in their source areas ${ }^{23}$, as well as through exchange processes with ocean margin sediments ${ }^{24}$. These characteristic $\mathrm{Nd}$-isotope compositions of deep-water masses are then conservatively advected and mixed over large distances in the open ocean given that the average $\mathrm{Nd}$ residence time of 400-2000 years is similar to the global ocean mixing time $^{23,25}$. Analysis of the Nd-isotope composition of authigenic sedimentary archives thus allows the reconstruction of changes in deep-water mixing over time.

Existing Late Cretaceous Atlantic seawater $\varepsilon_{\mathrm{Nd}(\mathrm{t})}$ signatures display a large spread in values (Fig. 1) that led to the suggestion that different mechanisms and locations of deep-water formation operated simultaneously ${ }^{21,26-30}$. There are indications that intermediate and deep-water exchange commenced as early as at $90 \mathrm{Ma}$ in the Late Turonian ${ }^{20}$, although the deep Atlantic Ocean potentially operated as a number of sub-basins with limited connectivity until the Maastrichtian ${ }^{22}$. The large variability in Cretaceous $\varepsilon_{\mathrm{Nd}(t)}$ values has so far been interpreted to reflect different modes and

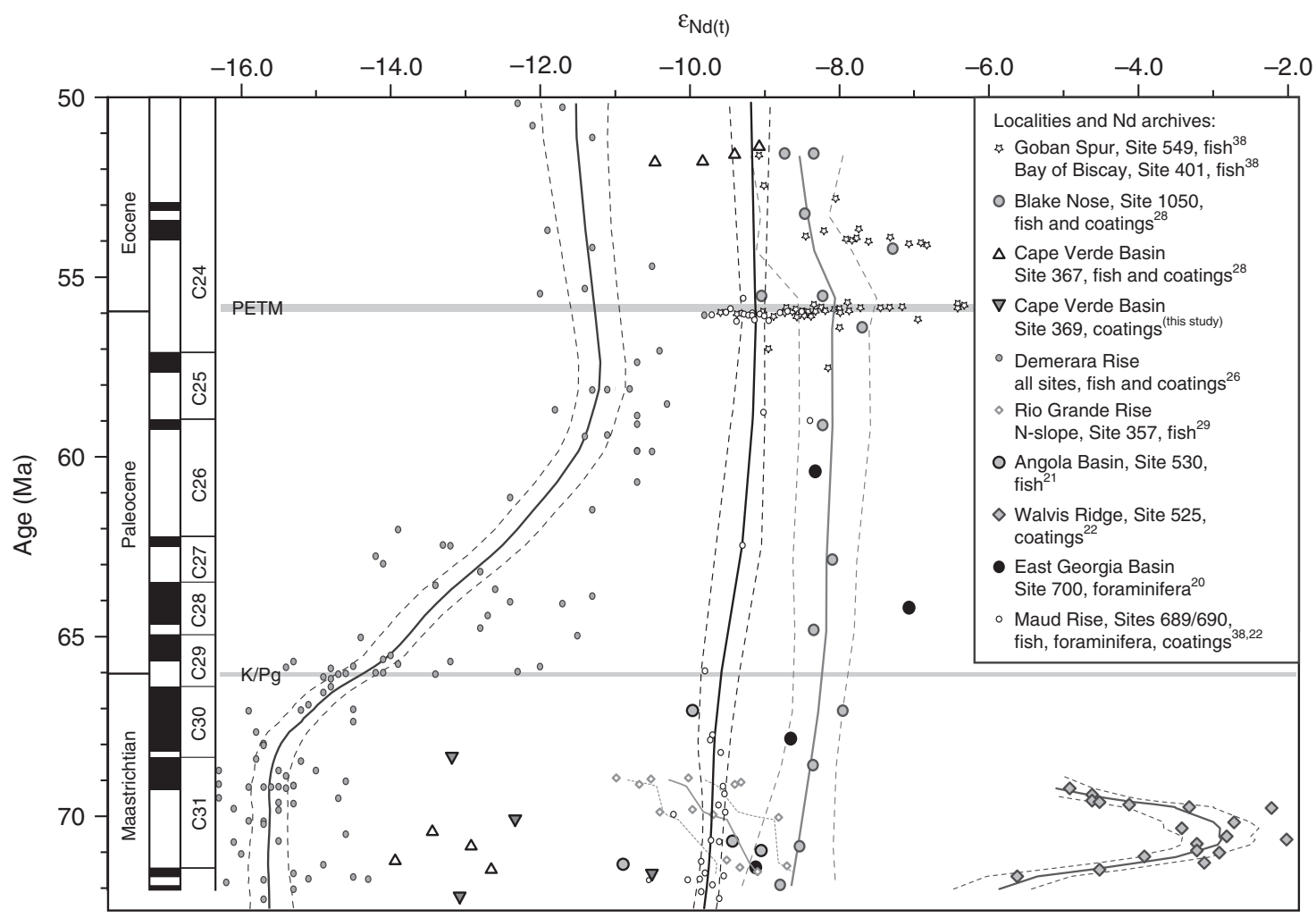

Fig. $1 \mathrm{Nd}$-isotope data across the latest Cretaceous - early Paleogene. In this compilation of published Atlantic $\varepsilon_{\mathrm{Nd}(\mathrm{t})}$ records and new Nd-isotope data from Site 369 (this study) only records with four or more data points over the time-interval 72-50 Ma are included. The $\varepsilon_{\mathrm{Nd}(\mathrm{t})}$ data of Demerara Rise (Sites 1258 , 1260, 1261), Maud Rise, Blake Nose and Site 525 have been smoothed by LOWESS regression $(f=0.3)$ with the dashed lines representing the $97.5 \%$ confidence interval. The $\varepsilon_{\mathrm{Nd}(t)}$ data are flanked by the geomagnetic polarity time scale with chrons C31-C24. PETM: Paleocene/Eocene thermal maximum, $\mathrm{K} / \mathrm{Pg}$ : Cretaceous/Paleogene Boundary 
locations of deep-water formation either in the southern high latitudes $21,22,29,30$ or in the North Atlantic ${ }^{26-28}$, or local deepwater formation in relatively shallow sub-basins separated at depth $^{22}$. The spread in $\varepsilon_{\mathrm{Nd}(\mathrm{t})}$ values was likely further enhanced by local boundary exchange and weathering inputs into the relatively small Atlantic basins. Since the Cretaceous Atlantic Ocean was limited in depth and width, its contact area with the margins was large compared to its volume. Regional processes such as boundary exchange thus had a profound effect on water-column chemistry, as is the case for modern near-shore settings ${ }^{24,31}$ or restricted sub-basins ${ }^{32}$. The Cretaceous Nd-isotope records from Demerara Rise and the Cape Verde Basin exemplify this effect by local weathering inputs of highly unradiogenic $\mathrm{Nd}$ from the old cratons of South America and Africa ${ }^{27,28}$ (Fig. 1). Despite the potential influence of continental inputs near ocean margins, several open-ocean sites in the Late Cretaceous North and South Atlantic show parallel Nd-isotope trends. These parallel trends have been interpreted to reflect the formation and northward flow of a southern-sourced deep-water mass, "Southern Component Water" 30 , although the behaviour of individual $\varepsilon_{\mathrm{Nd}(\mathrm{t})}$ records is highly variable on a time scale of millions of years and patterns of change are dissimilar between localities.

From the Paleocene-Eocene Thermal Maximum (PETM) at $56 \mathrm{Ma}$ onwards, most open-ocean $\varepsilon_{\mathrm{Nd}(\mathrm{t})}$ signatures from the North and South Atlantic were within a narrow range of -8 to $-10^{28,33,34}$, indicating common water masses at bathyal and abyssal depths. There is, however, a lack of data for the Paleocene, which limits our understanding of when and to what extent deep waters exchanged and when the Atlantic started to play a key role in hemispheric oceanic heat exchange. A compilation of existing $\varepsilon_{\mathrm{Nd}(\mathrm{t})}$ records for the period of time from 72 to $50 \mathrm{Ma}$ (Fig. 1) shows that $\mathrm{Nd}$-isotope data for the Paleocene are only available from a limited number of sites and, with the exception of Demerara Rise ${ }^{26,28}$, are of limited resolution (less than one sample per two million years). The Paleocene, however, marks the time when the Atlantic significantly widened and deepened, which potentially paved the way for similar-to-modern ocean overturning processes ${ }^{17}$. Here we fill this gap and present new Paleocene intermediate- and deep-water $\mathrm{Nd}$-isotope records from the North and South Atlantic Ocean. Five ocean drilling sites were selected from paleo-water depths between 500 and $4500 \mathrm{~m}$ (Supplementary Table 1/Fig. 2) to obtain seawater Nd-isotope records covering the critical time span from the end-Cretaceous to the early Paleogene.

\section{Results}

Seawater origin of Nd-isotope signatures. Seawater Nd-isotope signatures were obtained by leaching ferromanganese coatings of bulk sediments that are considered a reliable archive if sufficiently weak leaching procedures are applied ${ }^{35}$. The $\varepsilon_{\mathrm{Nd}(\mathrm{t})}$ variability of the detrital material was also determined for selected samples in this study (details in "methods" section), to evaluate the potential influence of local weathering inputs. The $\varepsilon_{\mathrm{Nd}(\mathrm{t})}$ signatures of the detrital fractions and the leached ferromanganese oxide coatings show similar long-term trends at Sites 516 and U1403 and parts of the records at Sites 1267 and 525. Despite following parallel trends, most detrital $\varepsilon_{\mathrm{Nd}(\mathrm{t})}$ values are significantly offset from those of the coatings supporting the validity of the seawater $\varepsilon_{\mathrm{Nd}(\mathrm{t})}$ signatures extracted from the coatings at the offshore locations of our studied sites as faithful recorders of past water mass mixing (Fig. 3). The Nd-isotope composition of the water-masses themselves may have been influenced to some extent by local factors such as boundary exchange processes that mainly occur when deep-water circulation is slow and/or the sites were located in small or partly isolated basins with high detrital input ${ }^{31,32,36}$.
In addition, the dissolved seawater $\mathrm{Nd}$-isotope signature may have been incorporated into the hydrogenous component of pelagic clays ${ }^{20,37}$, which may partly explain the similarity in the long-term evolution of the detrital and leached $\varepsilon_{\mathrm{Nd}(\mathrm{t})}$ values.

Parallel trends and convergence of Nd-isotope values. Our new seawater $\mathrm{Nd}$-isotope records from the North and South Atlantic (Fig. 3 and Supplementary Tables 2 to 6) display a wide range of values $(-2$ to -11$)$ in the Maastrichtian interval $(72.1-66 \mathrm{Ma})$ with parallel trends that converge to a common value of -8 to -9 at $59 \mathrm{Ma}$ (Fig. 4). Our North Atlantic record from Site U1403 ends at $58 \mathrm{Ma}$, but $\varepsilon_{\mathrm{Nd}(\mathrm{t})}$ values between -9.2 and 8 around 57 $\mathrm{Ma}$ at northern Site $549^{38}$ corroborate our findings (Fig. 1).

Sites 525, 1267 and 516 in the South Atlantic, and Site U1403 in the North Atlantic show a trend of decreasing $\varepsilon_{\mathrm{Nd}(\mathrm{t})}$ from approximately 70 to $63 \mathrm{Ma}$, with lowest values reached in the first half of the Paleocene. This decrease may reflect the reduction in active volcanism and exposed volcanic terrains in and around the Atlantic Ocean ${ }^{20}$. Nd-isotope values at Site 525 were positively offset from $\varepsilon_{\mathrm{Nd}(\mathrm{t})}$ signatures at comparably shallow Site 516 on the Rio Grande Rise and nearby deeper Site 1267 at the base of the north-western slope of the Walvis Ridge until the end of the Cretaceous. This positive offset was most likely caused by the weathering influx of volcanic material from the partially subaerially exposed Walvis Ridge in the latest Cretaceous ${ }^{15,39}$. The offset decreased as the ridge and Site 525 subsided.

From approximately $64 \mathrm{Ma}$ onwards, average $\varepsilon_{\mathrm{Nd}(\mathrm{t})}$ values display an increasing trend until 60-59 Ma. We assign this trend to the enhanced volumetric flow of deep and intermediate water masses in the opening South Atlantic Basin which likely led to a decrease of the influence of local inputs and boundary change effects. In addition, the observed trend coincides with a first phase of magmatic activity of the North Atlantic Igneous Province from 62 to $61 \mathrm{Ma}^{13}$, which may have supplied radiogenic $\mathrm{Nd}$, and ongoing deepening of the study sites that may have reduced unradiogenic weathering inputs from nearby continents.

From $59 \mathrm{Ma}$ onwards, the $\mathrm{Nd}$-isotope signatures at all newly studied sites, as well as Demerara Rise ${ }^{26}$, decrease together and our $\varepsilon_{\mathrm{Nd}(\mathrm{t})}$ results fall within a narrow range of -7 to -9.5 for the period 58.5-56.5 Ma. This convergence may reflect increasing admixture of southern-sourced deep water, which would have carried a $\varepsilon_{\mathrm{Nd}(\mathrm{t})}$ signature similar to that at Maud Rise of approximately -9 in the Paleocene (Fig. 4$)^{20}$.

Opening of the Atlantic Ocean and climatic implications. Recent paleobathymetric reconstructions show that deep oceanic basins in the Atlantic Ocean, like the Cape and the Angola basins, were constricted until the end of the Cretaceous ${ }^{15}$. Deeper structures, such as the Vema and Hunter channels flanking Rio Grande Rise only allowed intermediate-water exchange at depths shallower than $2500 \mathrm{~m}$. In the Paleocene, the South Atlantic deepened and widened, with the western portion of the Rio Grande Rise having subsided below $2500 \mathrm{~m}$ water depth at $60 \mathrm{Ma}$ and the Argentine and Brazil basins reaching depths of over 5500 $\mathrm{m}$ in the early Eocene $\mathrm{E}^{15,40}$ (Fig. 2). The close correspondence in $\varepsilon_{\mathrm{Nd}(\mathrm{t})}$ signatures at $59 \mathrm{Ma}$ suggests a common deep-water signature $\left(\varepsilon_{\mathrm{Nd}(\mathrm{t})}-9\right.$ to -8$)$ in the South and North Atlantic (Fig. 4). We interpret the converging trend of $\mathrm{Nd}$-isotope signatures to reflect an increasingly efficient deep-ocean circulation in the Atlantic Ocean with the dominant deep-water masses most likely originating in the high southern latitudes. Such a southern origin of deep water is consistent with recent modelling results ${ }^{17}$ suggesting locations of major deep-water formation in the Southern Ocean, potentially supplemented by a minor source of deep water formed offshore North America. At the same time, our data show 
a

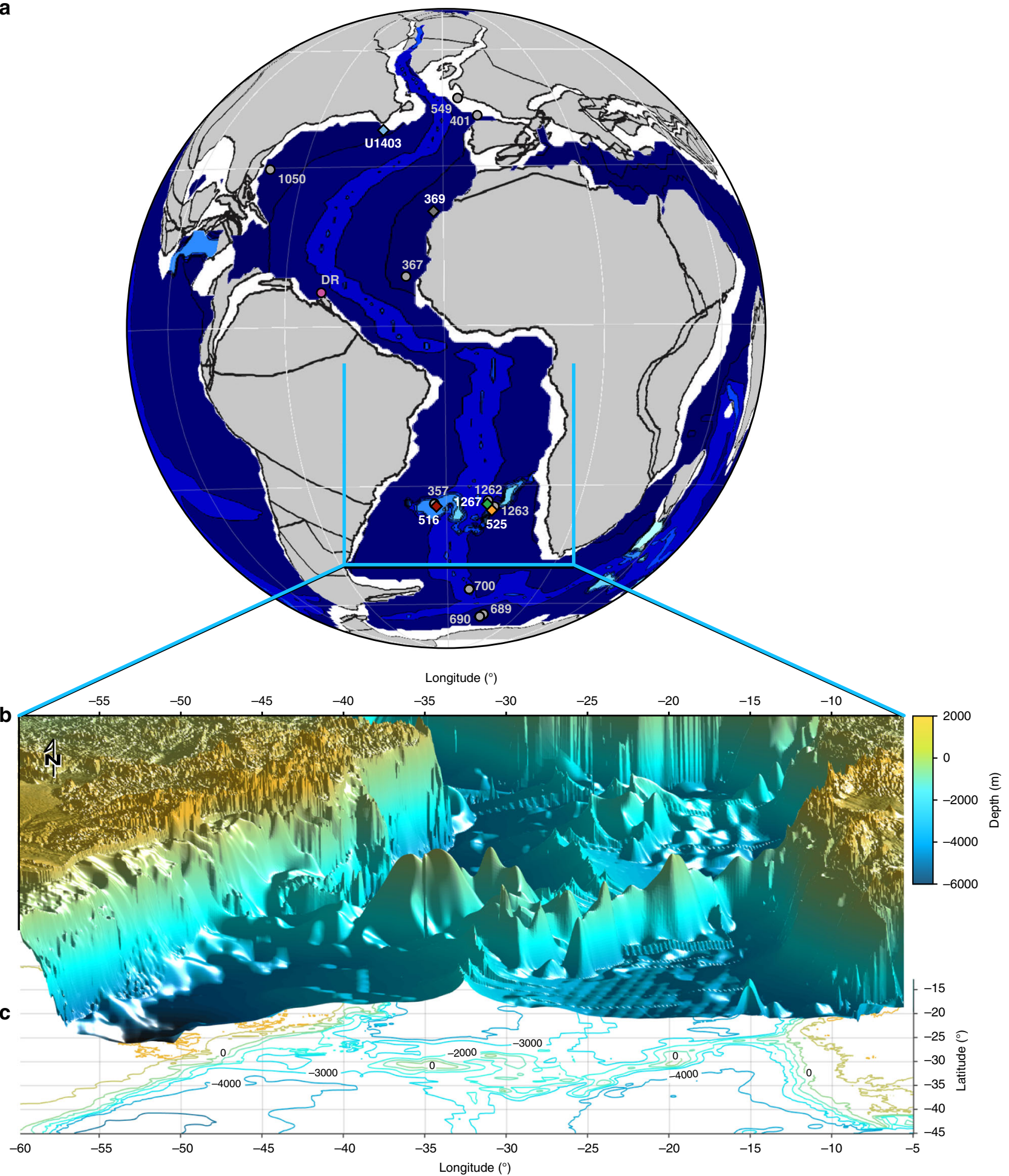

Fig. 2 Paleogeographic setting. a Paleogeographic reconstruction at $60 \mathrm{Ma}$. Plate tectonic configuration after ref. ${ }^{63}$ and global bathymetry from ref. 39 . Circles indicate Atlantic Ocean drilling sites for which Nd-isotope data are available (at least four points in the time-interval 72-50 Ma), DR: Demerara Rise. Diamonds indicate locations for which new data are presented here. Numbers indicate DSDP/ODP/IODP Sites. b Three-dimensional plot of the reconstructed bathymetry of the South Atlantic with the Rio Grande Rise - Walvis Ridge barrier at $60 \mathrm{Ma}$ from ref. ${ }^{40}$. c Contour plot of the bathymetry in panel $B$, with black numbers indicating depths in meters

that the sub-basins of the deep Atlantic became fully connected by subsidence of the Rio Grande Rise near $59 \mathrm{Ma}$, accompanied by the widening and deepening of the equatorial gateway ${ }^{17,20}$. The improved connectivity and the increased volumetric exchange of water masses in the Atlantic Ocean at $59 \mathrm{Ma}$ allowed modern-like open-ocean processes and water-mass mixing to be established, which decreased the sensitivity of the Nd-isotope composition of seawater to local effects such as terrigenous and coastal sedimentary inputs. The convergence of Nd-isotope signatures across the entire Atlantic Ocean spanning paleo- 


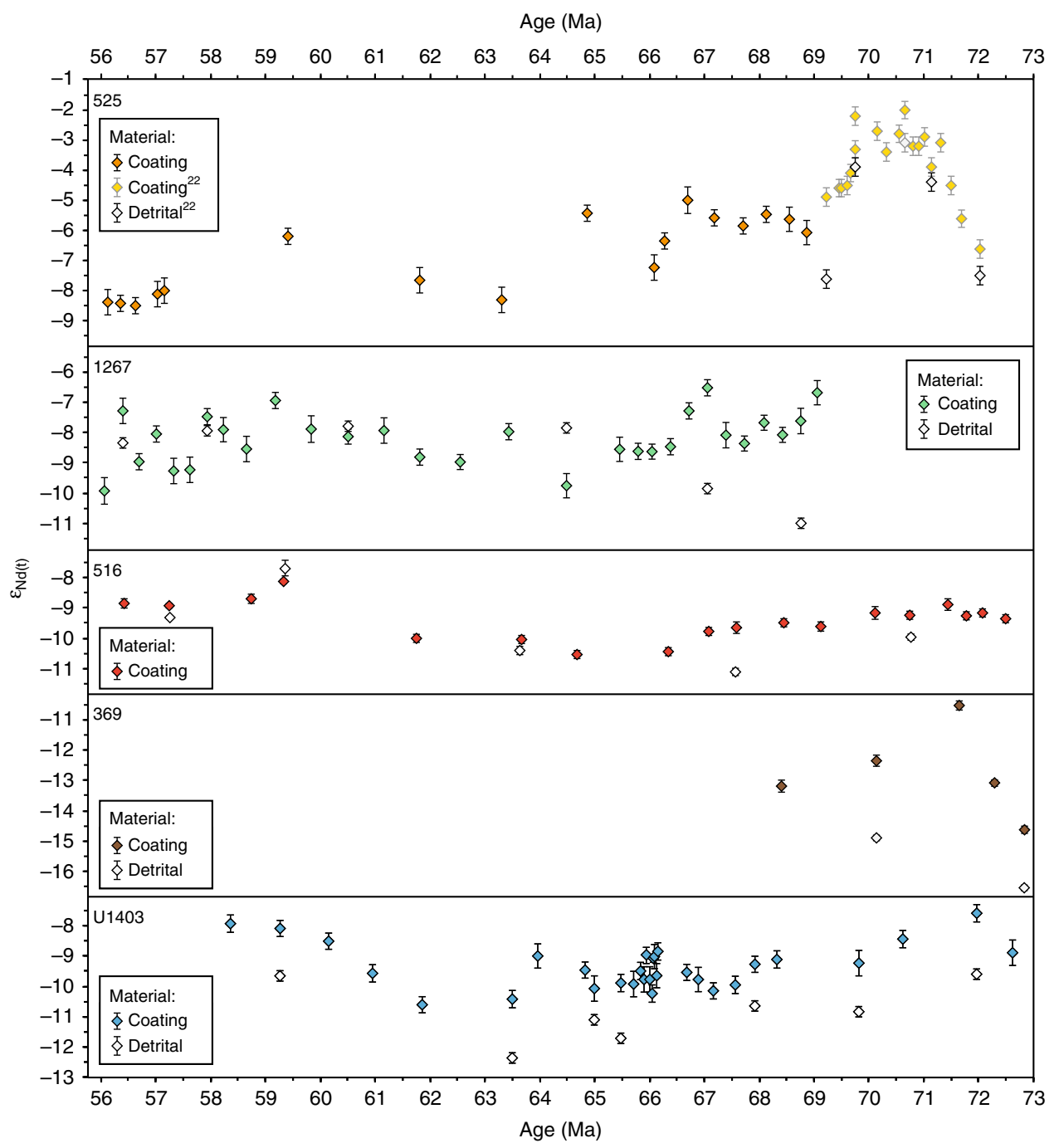

Fig. $3 \mathrm{New}$ Nd-isotope results. Neodymium isotope values of ferromanganese coatings (coloured symbols) and detrital fractions (open symbols) measured in this study and previously for Site $525^{22}$. Error bars indicate 2 s.d. external reproducibility

waterdepths of 500 to $4500 \mathrm{~m}$, further suggests that between 62 and $59 \mathrm{Ma}$, both local tectonic restrictions as well as the vertical stratification of the deep Atlantic Ocean decreased and a global mode of thermohaline circulation was initiated.

The close correspondence in Nd-isotope values among sites at $59 \mathrm{Ma}$ coincided with the onset of the mid-Paleocene global climate warming as evident from benthic foraminiferal oxygen isotopes ${ }^{13,41}$ (Fig. 4). Based on a recent reconstruction of continental rift length histories ${ }^{11}$ in comparison to the longterm evolution of atmospheric $\mathrm{pCO}_{2}^{8}$, the underlying cause of this warming may lie in the increased cumulative length of incipient continental rifts. Despite a reconstructed gradual increase in $\mathrm{pCO}_{2}$ levels during the end of the Cretaceous and earliest Paleocene ${ }^{8,11}$ (Fig. 4), as well as an initial magmatic phase of the North Atlantic Igneous Province from 62 to $61 \mathrm{Ma}^{13}$, the long-term increasing trend in bottom-water temperatures did not start until $59 \mathrm{Ma}^{13,41}$, when $\mathrm{pCO}_{2}$ started to increase at a higher rate ${ }^{8,11}$ (Fig. 4).

\section{Discussion}

We hypothesize that the strengthened Atlantic overturning circulation suggested by our data enhanced oceanic poleward heat transport thereby contributing to global climate warming culminating in the peak greenhouse conditions of the Eocene. Global warming may itself have enhanced vertical mixing through increased occurrence of storms and cyclones ${ }^{42}$ that enabled more efficient overturning circulation in the Atlantic Ocean. Both the deepening of the Rio Grande Rise and enhanced mixing associated with global warming would have increased the capacity of the overturning circulation in the Atlantic Ocean to transport heat. These interpretations of our new Nd-isotope data are consistent with observed changes in Late Cretaceous to early Paleogene Nd-isotope records from the Pacific Ocean ${ }^{42}$ and Earth system modelling results, which indicate that vigorous ocean circulation and strong vertical mixing resulted in increased oceanic heat transport and reduced equator-pole temperature gradients ${ }^{42,43}$. Higher oceanic heat transport efficiency likely also set the stage for the occurrence of brief hyperthermals which were frequently superimposed on the overall temperature rise of the Eocene hothouse ${ }^{41}$. Together with increasing atmospheric $\mathrm{CO}_{2}$ levels ${ }^{8,11}$, the changing paleogeography of the Atlantic Ocean may have contributed to the boundary conditions that pushed the Earth's climate into a greenhouse state.

\section{Methods}

Extraction of $\mathbf{N d}$ isotopes. For Nd-isotope analyses of past seawater extracted from ferromanganese oxide coatings, bulk sediment samples consisting mainly of nannofossil oozes and chalks were dried and homogenised in an agate mortar. To extract the authigenic, seawater-derived $\mathrm{Nd}$-isotope signature, $\sim 2.5 \mathrm{~g}$ of powder 


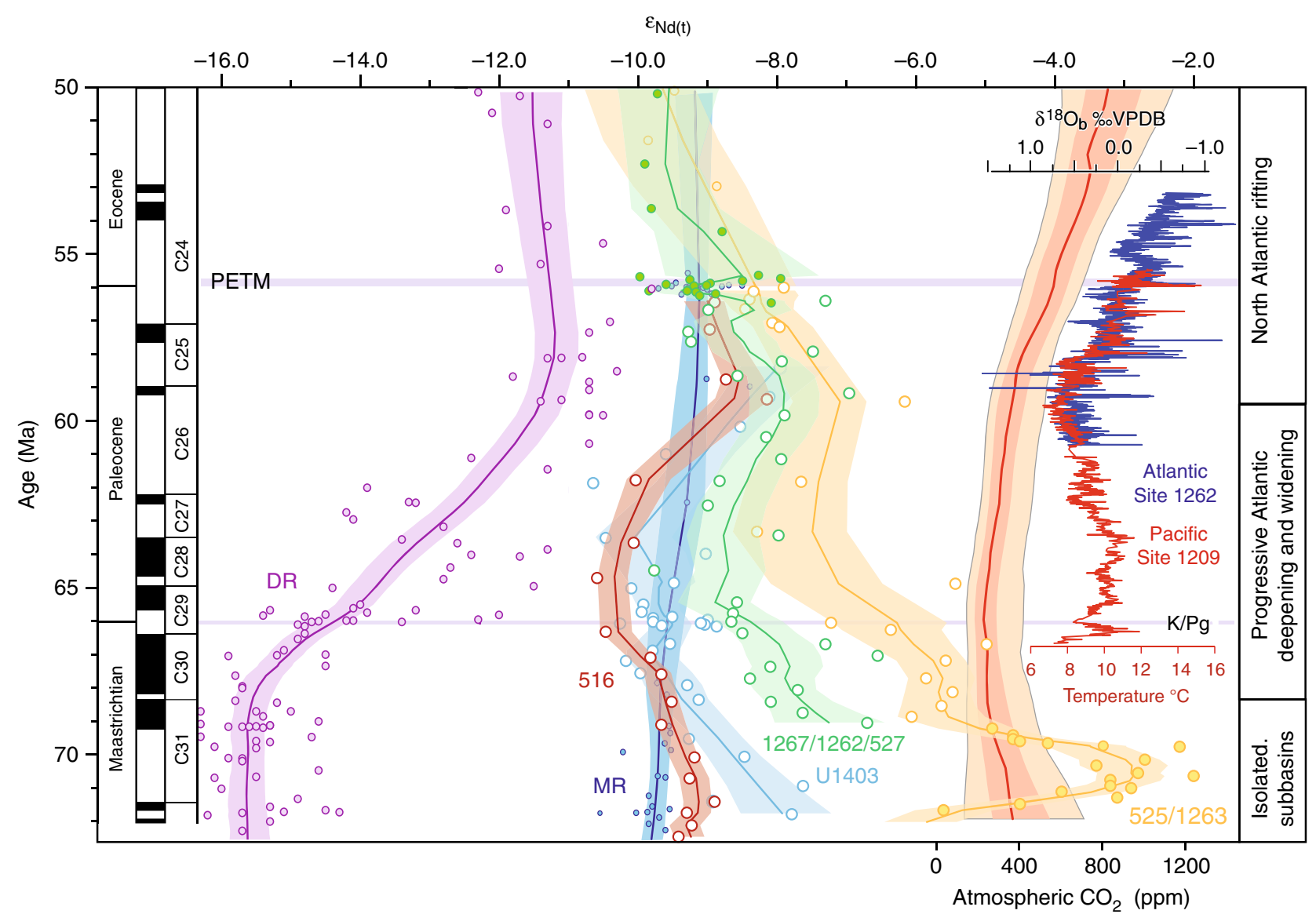

Fig. 4 The convergence of $\mathrm{Nd}$-isotope values. Maastrichtian to early Eocene $\mathrm{Nd}$-isotope records compared to atmospheric $\mathrm{CO}_{2}$ levels and deep-sea temperature evolution. Open symbols depict new $\varepsilon_{\mathrm{Nd}(t)}$ data for North Atlantic Site U1403 (Newfoundland margin, dark blue) and South Atlantic Sites 516 (Rio Grande Rise, red), 1267 (northern flank of the Walvis Ridge, green) and 525 (top of the Walvis Ridge, yellow). Filled symbols depict selected highresolution $\varepsilon_{\mathrm{Nd}(t)}$ data from Demerara Rise in the North Atlantic ${ }^{26,28}$ (purple), Sites $527^{33}$ and $1262^{34}$ on the flank of the Walvis Ridge (green), Site $1263^{34}$ and Site $525^{22}$ on the Walvis Ridge (yellow), and Maud Rise in the Southern Ocean ${ }^{20}$ (dark blue). The $\varepsilon_{\mathrm{Nd}(\mathrm{t})}$ data have been smoothed by LOWESS regression $(f=0.3)$ with the shaded areas representing the $97.5 \%$ confidence interval. The $\varepsilon_{\mathrm{Nd}(t)}$ data are flanked by the geomagnetic polarity time scale on the left and on the right by reconstructed atmospheric $\mathrm{CO}_{2}$ levels ${ }^{11}$, benthic oxygen isotope data from the Pacific ${ }^{41}$ and the Atlantic ${ }^{13}$, and the suggested evolution of the Atlantic Ocean. The Paleogene age model of the Sites rests on a combination of magnetic and nannofossil stratigraphy plotted against the GTS 201264. C31-C24: paleomagnetic chrons, $\delta^{18} \mathrm{O}_{\mathrm{b}}$ : oxygen isotope ratio from benthic foraminifera, VPDB: Vienna Pee Dee Belemnite standard, PETM: Paleocene/Eocene Thermal Maximum, DR: Demerara Rise, K/Pg: Cretaceous/Paleogene boundary, MR: Maud Rise

was treated following the procedure described in ref. ${ }^{44}$, omitting the carbonate removal step ${ }^{45}$. Powdered samples were rinsed three times with de-ionized (MQ) water, after which $10 \mathrm{ml}$ of MQ was added and $10 \mathrm{ml}$ of a $0.05 \mathrm{M}$ hydroxylamine hydrochloride/ $15 \%$ acetic acid solution, buffered with $\mathrm{NaOH}$ to a $\mathrm{pH}$ of 4 . Samples were placed on a shaker for $1 \mathrm{~h}$ and centrifuged. The supernatant containing the seawater $\mathrm{Nd}$-isotope signature of the ferromanganese oxide coatings was pipetted off and dried down. For determining the detrital $\varepsilon_{\mathrm{Nd}}$ signature, selected samples underwent an additional $12 \mathrm{~h}$ leaching step with $20 \mathrm{ml}$ of the hydroxylamine solution (above), after which samples were rinsed with MQ three times and $\sim 50 \mathrm{mg}$ of dried sample was dissolved in a mixture of aqua regia and HF. As preparatory steps for column chemistry, all samples were refluxed in concentrated $\mathrm{HNO}_{3}$ at $80^{\circ} \mathrm{C}$ overnight, centrifuged, and $80 \%$ of the supernatant was dried down. Twice, $0.5 \mathrm{ml}$ of $1 \mathrm{M} \mathrm{HCl}$ was added and the sample was dried down, after which the samples were redissolved in $0.5 \mathrm{ml} 1 \mathrm{M} \mathrm{HCl}$. Samples were passed through cationexchange columns with $0.8 \mathrm{ml}$ AG50W-X12 resin (mesh size 200-400 $\mu \mathrm{m}$ ), using standard procedures, to separate $\mathrm{Sr}$ and the Rare Earth Elements (REEs), as well as removing most of the $\mathrm{Ba}^{46}$. A second set of columns with $2 \mathrm{ml} \mathrm{Ln}$-Spec resin (mesh size $50-100 \mu \mathrm{m}$ ) was used to separate $\mathrm{Nd}$ from the other REEs and remaining $\mathrm{Ba}^{47}$.

Analytical procedure. Neodymium isotope ratios were measured on a $\mathrm{Nu}$ Instruments Multiple Collector Inductively Coupled Plasma Mass Spectrometer (MC-ICPMS). The majority of samples were measured at GEOMAR Kiel, Germany, and a subset of samples at the department of Earth Sciences of Oxford University, UK (Supplementary Tables 2, 5 and 6). Measured ${ }^{143} \mathrm{Nd} /{ }^{144} \mathrm{Nd}$ results were mass-bias corrected to a ${ }^{146} \mathrm{Nd} /{ }^{144} \mathrm{Nd}$ ratio of 0.7219 and were normalized to the accepted ${ }^{143} \mathrm{Nd} /{ }^{144} \mathrm{Nd}$ value of 0.512115 for the JNdi-1 standard ${ }^{48}$, which was measured after every third sample.

The results were decay-corrected for the time of deposition by $\left({ }^{143} \mathrm{Nd} /\right.$ $\left.{ }^{144} \mathrm{Nd}\right)_{\text {sample(t) }}=\left({ }^{143} \mathrm{Nd} /{ }^{144} \mathrm{Nd}\right)_{\text {sample }(0)}-\left[\left({ }^{147} \mathrm{Sm} /{ }^{144} \mathrm{Nd}\right)_{\text {sample }(0)} *\left(\mathrm{e}^{\mathrm{st}}-1\right)\right]$ where $t$ is time, the decay constant $\kappa$ is $6.54 \times 10^{-12}$, and using an average ${ }^{147} \mathrm{Sm} /{ }^{144} \mathrm{Nd}$ ratio of $0.124^{22}$. Nd-isotope ratios are reported as $\varepsilon_{\mathrm{Nd}(t)}$ values with respect to the Chondritic Uniform Reservoir (CHUR), which are calculated as $\varepsilon_{\mathrm{Nd}(t)}=\left[\left({ }^{143} \mathrm{Nd} /\right.\right.$ $\left.\left.{ }^{144} \mathrm{Nd}\right)_{\text {sample(t) }} /\left({ }^{143} \mathrm{Nd} /{ }^{144} \mathrm{Nd}\right)_{\mathrm{CHUR}(\mathrm{t})}-1\right] \times 10^{4}$ using a $\left({ }^{143} \mathrm{Nd} /{ }^{144} \mathrm{Nd}\right)_{\mathrm{CHUR}(0)}$ value of 0.512638 , and a $\left({ }^{147} \mathrm{Sm} /{ }^{144} \mathrm{Nd}\right)_{\mathrm{CHUR}(0)}$ of $0.1966^{49}$. External reproducibility $(2 \sigma)$ of the measurements was between 0.15 and $0.54 \varepsilon_{\mathrm{Nd}}$ units and procedural $\mathrm{Nd}$ blanks were $\leq 30 \mathrm{pg} \mathrm{Nd}$ and thus negligible.

Age models. Age models for the individual sites were generated by an integrated approach of magneto- and biostratigraphy and if available astrochronology. All datum levels are tied to the Geological Timescale GTS2012. Ages of polarity chrons are from ref. ${ }^{50}$, and of calcareous nannofossils (NP zonation) from ref. ${ }^{51}$ as compiled in ref. ${ }^{52}$. In detail the following data are used and summarized in Supplementary Table 7. Tie points for Site 516 are defined by magneto- and calcareous nannofossil stratigraphy given in ref. ${ }^{53}$. Tie points for Site 525 are defined by polarity chrons in the Maastrichtian ${ }^{54}$ and by calcareous nannofossils in the Paleocene ${ }^{55}$. Tie points for Site 1267 are derived from precession cycle counting for the upper Paleocene (until 58.2 Ma ago) ${ }^{56}$ and polarity chrons for the lower to middle Paleocene and the Maastrichtian ${ }^{57}$. Ages of neodymium isotope data from Site $1262^{34}$ and Site $527^{33}$ were converted to GTS 2012. Tie points for Site 369 follow the age model of the Shipboard Scientific Party ${ }^{58}$. Tie points for Site U1403 are defined by first occurrences (FO) of calcareous nannofossils for the Paleocene ${ }^{59}$ 
with an adjustment for the FO of Lithoptychius spp. at $227 \mathrm{~m}$ depth rCCSF (corresponding to the first radiation of fasciculithids according to refs. ${ }^{60,] 61}$ ) and by astronomical tuning of $405 \mathrm{kyr}$ cycles and carbon isotope stratigraphy ${ }^{62}$.

\section{Data availability}

The authors declare that all the data generated during this study are available within the manuscript and its supplementary information file.

Received: 8 March 2018 Accepted: 1 November 2018

Published online: 23 November 2018

\section{References}

1. Clarke, L. J. \& Jenkyns, H. C. New oxygen isotope evidence for long-term Cretaceous climatic change in the Southern Hemisphere. Geology 27, 699-702 (1999).

2. Cramer, B. S., Toggweiler, J. R., Wright, J. D., Katz, M. E. \& Miller, K. G. Ocean overturning since the Late Cretaceous: Inferences from a new benthic foraminiferal isotope compilation. Paleoceanography 24, PA4216 (2009)

3. Friedrich, O., Norris, R. D. \& Erbacher, J. Evolution of middle to Late Cretaceous oceans-A 55 m.y. record of Earth's temperature and carbon cycle. Geology 40, 107-110 (2012).

4. Huber, B. T., MacLeod, K. G., Watkins, D. K. \& Coffin, M. F. The rise and fall of the Cretaceous hot greenhouse climate. Glob. Planet. Change 167, 1-23 (2018).

5. Huber, B. T., Hodell, D. A. \& Hamilton, C. P. Middle-Late Cretaceous climate of the southern high latitudes: Stable isotopic evidence for minimal equatorto-pole thermal gradients. Geol. Soc. Am. Bull. 107, 1164-1191 (1995).

6. Zachos, J. C., Dickens, G. R. \& Zeebe, R. E. An early Cenozoic perspective on greenhouse warming and carbon-cycle dynamics. Nature 451, 279-283 (2008).

7. Anagnostou, E. et al. Changing atmospheric $\mathrm{CO}_{2}$ concentration was the primary driver of early Cenozoic climate. Nature 533, 380-384 (2016).

8. Foster, G. L., Royer, D. L. \& Lunt, D. J. Future climate forcing potentially without precedent in the last 420 million years. Nat. Commun. 8, 14845 (2017).

9. Pucéat, E. et al.Fish tooth $\delta^{18} \mathrm{O}$ revising Late Cretaceous meridional upper ocean water temperature gradients. Geology 35, 107-110 (2007).

10. Larson, R. L. Latest pulse of Earth: evidence for a mid-Cretaceous superplume. Geology 19, 547-550 (1991).

11. Brune, S., Williams, S. E. \& Müller, R. D. Potential links between continental rifting, $\mathrm{CO}_{2}$ degassing and climate change through time. Nat. Geosci. 10, 941-946 (2017).

12. Gutjahr, M. et al. Very large release of mostly volcanic carbon during the Palaeocene-Eocene thermal maximum. Nature 548, 573-577 (2017).

13. Westerhold, T., Röhl, U., Donner, B., McCarren, H. K. \& Zachos, J. C. A complete high-resolution Paleocene benthic stable isotope record for the central Pacific (ODP Site 1209). Paleoceanography 26, PA2216 (2011).

14. Pucéat, E., Lecuyer, C. \& Reisberg, L. Neodymium isotope evolution of NW Tethyan upper ocean waters throughout the Cretaceous. Earth Planet. Sci. Lett. 236, 705-720 (2005).

15. Pérez-Díaz, L. \& Eagles, G. South Atlantic paleobathymetry since early Cretaceous. Sci. Rep. 7, 11819 (2017).

16. Sewall, J. O. et al. Climate model boundary conditions for four Cretaceous time slices. Clim. Past. 3, 647-657 (2007).

17. Donnadieu, Y., Pucéat, E., Moiroud, M., Guillocheau, F. \& Deconinck, J.-F. A better-ventilated ocean triggered by Late Cretaceous changes in continental configuration. Nat. Commun. 7, 10316 (2016).

18. Frank, T. D. \& Arthur, M. A. Tectonic forcings of Maastrichtian ocean-climate evolution. Paleoceanography 14, 103-117 (1999).

19. Friedrich, O. \& Erbacher, J. Benthic foraminiferal assemblages from Demerara Rise (ODP Leg 207, western tropical Atlantic): possible evidence for a progressive opening of the Equatorial Atlantic Gateway. Cretac. Res. 27, 377-397 (2006).

20. Moiroud, M. et al. Evolution of neodymium isotopic signature of seawater during the Late Cretaceous: implications for intermediate and deep circulation. Gondwana Res. 36, 503-522 (2015).

21. Robinson, S. A., Murphy, D. P., Vance, D. \& Thomas, D. J. Formation of "Southern Component Water" in the Late Cretaceous: evidence from $\mathrm{Nd}$ isotopes. Geology 38, 871-874 (2010).

22. Voigt, S. et al.Tectonically restricted deep-ocean circulation at the end of the Cretaceous greenhouse. Earth Planet. Sci. Lett. 369-370, 169-177 (2013).

23. Frank, M. Radiogenic isotopes: tracers of past ocean circulation and erosional input. Rev. Geophys. 40, https://doi.org/10.1029/2000RG000094 (2002).

24. Lacan, F. \& Jeandel, C. Neodymium isotopes as a new tool for quantifying exchange fluxes at the continent-ocean interface. Earth Planet. Sci. Lett. 232, 245-257 (2005).
25. Rempfer, J., Stocker, T. F., Joos, F., Dutay, J.-C. \& Siddall, M. Modelling Ndisotopes with a coarse resolution ocean circulation model: Sensitivities to model parameters and source/sink distributions. Geochim. Cosmochim. Acta 75, 5927-5950 (2011)

26. MacLeod, K. G., Isaza Londoño, C., Martin, E. E., Jiménez Berrocoso, Á. \& Basak, C. Changes in North Atlantic circulation at the end of the Cretaceous greenhouse interval. Nat. Geosci. 4, 779-782 (2011)

27. MacLeod, K. G., Martin, E. E. \& Blair, S. W. Nd isotopic excursion across Cretaceous ocean anoxic event 2 (Cenomanian-Turonian) in the tropical North Atlantic. Geology 36, 811-814 (2008).

28. Martin, E. E., MacLeod, K. G., Jiménez Berrocoso, A. \& Bourbon, E. Water mass circulation on Demerara Rise during the Late Cretaceous based on $\mathrm{Nd}$ isotopes. Earth Planet. Sci. Lett. 327-328, 111-120 (2012).

29. Murphy, D. P. \& Thomas, D. J. The evolution of Late Cretaceous deep-ocean circulation in the Atlantic basins: Neodymium isotope evidence from South Atlantic drill sites for tectonic controls. Geochem. Geophys. Geosystems 14, 5323-5340 (2013)

30. Robinson, S. A. \& Vance, D. Widespread and synchronous change in deepocean circulation in the North and South Atlantic during the Late Cretaceous. Paleoceanography 27, PA1102 (2012).

31. Grasse, P. et al. Short-term variability of dissolved rare earth elements and neodymium isotopes in the entire water column of the Panama Basin. Earth Planet. Sci. Lett. 475, 242-253 (2017).

32. Osborne, A. H., Haley, B. A., Hathorne, E. C., Flögel, S. \& Frank, M. Neodymium isotopes and concentrations in Caribbean seawater: Tracing water mass mixing and continental input in a semi-enclosed ocean basin. Earth Planet. Sci. Lett. 406, 174-186 (2014).

33. Abbott, A. N., Haley, B. A., Tripati, A. K. \& Frank, M. Constraints on ocean circulation at the Paleocene-Eocene Thermal Maximum from neodymium isotopes. Clim. Past Discuss. 11, 2557-2583 (2015).

34. Via, R. K. \& Thomas, D. J. Evolution of Atlantic thermohaline circulation: Early Oligocene onset of deep-water production in the North Atlantic. Geology 34, 441-444 (2006).

35. Blaser, P. et al. Extracting foraminiferal seawater $\mathrm{Nd}$ isotope signatures from bulk deep sea sediment by chemical leaching. Chem. Geol. 439, 189-204 (2016).

36. Yu, Z. et al. Seasonal variations in dissolved neodymium isotope composition in the Bay of Bengal. Earth Planet. Sci. Lett. 479, 310-321 (2017).

37. Goldstein, S. L. \& O'Nions, R. K. Nd and Sr isotopic relationships in pelagic clays and ferromanganese deposits. Nature 292, 324-327 (1981).

38. Thomas, D. J., Bralower, T. J. \& Jones, C. E. Neodymium isotopic reconstruction of late Paleocene-early Eocene thermohaline circulation. Earth Planet. Sci. Lett. 209, 309-322 (2003).

39. Müller, R. D., Sdrolias, M., Gaina, C., Steinberger, B. \& Heine, C. Long-term sea-level fluctuations driven by ocean basin dynamics. Science 319, 1357-1362 (2008).

40. Pérez-Díaz, L. \& Eagles, G. Estimating palaeobathymetry with quantified uncertainties: a workflow illustrated with South Atlantic data. Geol. Soc. Lond. Spec. Publ. SP476, 1 (2018).

41. Littler, K., Röhl, U., Westerhold, T. \& Zachos, J. C. A high-resolution benthic stable-isotope record for the South Atlantic: Implications for orbital-scale changes in Late Paleocene-Early Eocene climate and carbon cycling. Earth Planet. Sci. Lett. 401, 18-30 (2014).

42. Thomas, D. J., Korty, R., Huber, M., Schubert, J. A. \& Haines, B. Nd isotopic structure of the Pacific Ocean 70-30 Ma and numerical evidence for vigorous ocean circulation and ocean heat transport in a greenhouse world. Paleoceanography 29, 454-469 (2014)

43. Sijp, W. P. \& England, M. H. The effect of low ancient greenhouse climate temperature gradients on the ocean's overturning circulation. Clim. Past. 12 , 543-552 (2016).

44. Gutjahr, M. et al. Reliable extraction of a deepwater trace metal isotope signal from Fe-Mn oxyhydroxide coatings of marine sediments. Chem. Geol. 242, 351-370 (2007)

45. Stumpf, R., Frank, M., Schönfeld, J. \& Haley, B. A. Late Quaternary variability of Mediterranean outflow water from radiogenic $\mathrm{Nd}$ and $\mathrm{Pb}$ isotopes. Quat. Sci. Rev. 29, 2462-2472 (2010).

46. Barrat, J. et al. Determination of rare earth elements in sixteen silicate reference samples by ICP_MS after Tm addition and ion exchange separation. Geostand. Newsl. 20, 133-139 (1996).

47. Le Fèvre, B. \& Pin, C. A straightforward separation scheme for concomitant $\mathrm{Lu}-\mathrm{Hf}$ and $\mathrm{Sm}-\mathrm{Nd}$ isotope ratio and isotope dilution analysis. Anal. Chim. Acta 543, 209-221 (2005).

48. Tanaka, T. et al. JNdi-1: a neodymium isotopic reference in consistency with LaJolla neodymium. Chem. Geol. 168, 279-281 (2000).

49. Jacobsen, S. B. \& Wasserburg, G. J. Sm-Nd isotopic evolution of chondrites. Earth Planet. Sci. Lett. 50, 139-155 (1980).

50. Ogg, J. G. Geomagnetic Polarity Time Scale. in: The Geological Time Scale Vol. 1 (eds Gradstein, F. M., Ogg, J. G., Schmitz, M. D. \& Ogg, G.) 85-113 (Elsevier, Amsterdam, 2012). 
51. Berggren, W. A., Kent, D. V., Swisher, C. C. \& Aubry, M.-P. A Cenozoic geochronology and chronostratigraphy. Soc. Sed. Geol. Spec. Publ. 54, 129-212 (1995).

52. Anthonissen, D. E. \& Ogg, J. G. Cenozoic and Cretaceous biochronology of planktonic foraminifera and calcareous nannofossils. in: The Geological Time Scale Vol. 2 (eds Gradstein, F. M., Ogg, J. G., Schmitz, M. D. \& Ogg, G.) 1083-1027 (Elsevier, Amsterdam, 2012).

53. Berggren, W. A. et al. Magnetobiostratigraphy of Deep Sea Drilling Project leg 72, Sites 515-518, Rio Grande Rise (South Atlantic). In: Barker, P.F. et al., Init. Rep. Deep Sea Drill. Proj. 72, 938-948 (1983).

54. Chave, A. D. Lower Paleocene-Upper Cretaceous magnetostratigraphy, Sites 525, 527, 528, and 529, Deep Sea Drilling Project Leg 74. In: Moore, T.C. et al. Init. Rep. Deep Sea Drill. Proj. 74, 525-531 (1984).

55. Manivit, H. Paleogene and Upper Cretaceous calcareous nannofossils from Deep Sea Drilling Project Leg 74. In: Moore, T.C. et al. Init. Rep. Deep Sea Drill. Proj. 74, 475-499 (1984).

56. Westerhold, T. et al. On the duration of magnetochrons C24r and C25n and the timing of early Eocene global warming events: Implications from the Ocean Drilling Program Leg 208 Walvis Ridge depth transect. Paleoceanography 22, PA2201 (2007).

57. Zachos, J. C. et al. In: Leg 208 summary. Proc. Ocean Drill. Prog Init. Rep. 208, 1-112 (2004).

58. Lancelot, Y. Seibold, E., et al. Volume 41. Init. Rep. Deep Sea Drill. Proj. 41, (U. S. Government Printing Office, Washington, 1977).

59. Norris, R. D., Wilson, P. A., Blum, P. \& Expedition 342 Scientists. Site 1403. In: Paleogene Newfoundland Sediment Drifts and MDHDS Test. Proc. Integrat. Ocean Drill. Prog. 342, (2014).

60. Monechi, S., Reale, V., Bernaola, G. \& Balestra, B. The Danian/Selandian boundary at Site 1262 (South Atlantic) and in the Tethyan region: biomagnetostratigraphy, evolutionary trends in fasciculiths and environmental effects of the Latest Danian Event. Mar. Micro. 98, 28-40 (2013).

61. Dinarès-Turell, J., Westerhold, T., Pujalte, V., Röhl, U. \& Kroon, D. Astronomical calibration of the Danian stage (Early Paleocene) revisited: Settling chronologies of sedimentary records across the Atlantic and Pacific Oceans. Earth Planet. Sci. Lett. 405, 119-131 (2014).

62. Batenburg, S. J. et al. Late Maastrichtian carbon isotope stratigraphy and cyclostratigraphy of the Newfoundland Margin (Site U1403, IODP Leg 342). Newsl. Stratigr. 51, 245-260 (2018).

63. Hay, W. W. et al. Alternative global Cretaceous paleogeography. In: Special Paper 332: Evolution of the Cretaceous Ocean-Climate System 1-47 (Geological Society of America, Boulder, Colorado, 1999).

64. Gradstein, F., Ogg, J., Schmitz, M. \& Ogg, G. (Eds) The Geologic Time Scale 2012 (Elsevier, Amsterdam, 2012).

\section{Acknowledgements}

We would like to thank the International Ocean Discovery Program (IODP) for providing samples. Authors were funded by the German Research Foundation (DFG) under grant numbers DFG VO 687/14, FR2544/8, and FR1198/11, BO2505/8 and EH89/20. We would like to thank Jutta Heinze and Chris Siebert at GEOMAR, Kiel and Alan Hsieh at Oxford University, UK for smooth operation of the laboratory and the mass spectrometers.

\section{Author contributions}

S.J.B., S.V., O.F. and M.F. developed the project. S.J.B., A.H.O. and T.K. performed Ndisotope analyses. L.P-D. provided bathymetric information. All authors contributed to the writing of the manuscript.

\section{Additional information}

Supplementary Information accompanies this paper at https://doi.org/10.1038/s41467 018-07457-7.

Competing interests: The authors declare no competing interests.

Reprints and permission information is available online at http://npg.nature.com/ reprintsandpermissions/

Publisher's note: Springer Nature remains neutral with regard to jurisdictional claims in published maps and institutional affiliations.

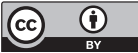

Open Access This article is licensed under a Creative Commons Attribution 4.0 International License, which permits use, sharing, adaptation, distribution and reproduction in any medium or format, as long as you give appropriate credit to the original author(s) and the source, provide a link to the Creative Commons license, and indicate if changes were made. The images or other third party material in this article are included in the article's Creative Commons license, unless indicated otherwise in a credit line to the material. If material is not included in the article's Creative Commons license and your intended use is not permitted by statutory regulation or exceeds the permitted use, you will need to obtain permission directly from the copyright holder. To view a copy of this license, visit http://creativecommons.org/ licenses/by/4.0/

(C) The Author(s) 2018 